\title{
KEWENANGAN PENGADILAN MILITER UTAMA DALAM MELAKUKAN PENGAWASAN PERADILAN MILITER
}

\author{
Raditya Feda Rifandhana \\ Fakultas Hukum Universitas Merdeka Malang \\ Jl.Terusan Raya Dieng No 62-64 Malang \\ Email: adietz_008@yahoo.com
}

\begin{abstract}
Alegal state synonymous with unitary state of indonesia has basic rules are in perundang-undangan undangundang the basis of the republic of indonesia in 1945, on the country unity of indonesia there are three about famous in triassic politica, namely executive, legislative and judicial, who masing-masing has the authority to supervision masing-masing institution in unitary state institutions republic indonesia.pada judiciary have jurisdiction surveillance on judicial environment, in this case is the military court is the main of military courts.
\end{abstract}

Keywords: Law State, Authority, Military Court, Superivision.

\begin{abstract}
Abstrak
Negara Hukum identik dengan Negara Kesatuan Republik Indonesia yang memiliki dasar di Peraturan Perundang-Undangan yakni Undang-Undang Dasar Negara Republik Indonesia Tahun 1945, pada Negara Kesatuan Republik Indonesia terdapat tiga ajaran yang terkenal pada trias politica, yakni eksekutif, legislatif dan yudikatif, yang masing-masing memiliki kewenangan terhadap pengawasan masing-masing lembaga di Negara Kesatuan Republik Indonesia.Pada Lembaga Yudikatif memiliki kewenangan pengawasan pada lingkungan peradilan, dalam hal ini adalah lingkungan peradilan militer yang merupakan kewenangan dari Pengadilan Militer Utama.
\end{abstract}

Kata Kunci: Kewenangan, Negara Hukum, Pengawasan, Peradilan Militer.

Dari segi historis, Negara Hukum sebagai suatu istilah,yang merupakan terjemahan dari rechtsstaat atau the rule of law. Adalah teori yang secara historis bermula dari Yunani, ditulis oleh Plato dalam bukunya secara berturut-turut Politieia, Politicos dan Nomoi. Plato dengan gagasan negara idealnya (yang untuk selanjutnya berkembang menjadi gagasan Negara Hukum) memimpikan bahwa negara tidak diperintah oleh kekuasaan serta orang-orang yang bebas, melainkan oleh penguasa yang menjalankan pemerintahannya dengan keadilan berdasarkan norma-norma yang tertulis. Ketika itu, penguasa adalah hamba-hamba hukum yang tidak membedabedakan orang. Gagasannya itu kemudian diteruskan oleh muridnya, Aristoteles, dengan bukunya Politica, Negara Hukum itu, meski bukan alternatif yang terbaik dibanding dengan negara yang dipimpin oleh cerdik cendikiawan, sebagaimana yang diidealkan oleh Plato, namun adalah cara yang paling praktis guna mencapai kehidupan masyarakat yang baik dan sejahtera. 
Terkait dengan hukum, Aristoteles berpendapat bahwa hukum itu merupakan pembadanan dari akal yang terbebas oleh nafsu dari orangorang yang menjalankan pemerintahan. Namun demikian, hukum itu dapat saja keras dan mengandung kemungkinan terjadinya ketidakadilan. Untuk itu, hukum harus dilunakkan dengan mendekatkan kepada keadilan melalui cara equity. Suatu cara penerapan hukum yang bersifat umum pada kasus kongkrit yang bersifat khusus dengan menyesuaikan pada keunikan kasus tersebut (ius suum cuique tribuere). Ketika itu hakim yang mengambil keputusan terhadap kasus itu menerapkan hukum seperti pada posisi pembuat hukum. Hakim prasyarat independensi dan imparsialitas. Keduanya bermakna keharusan tiadanya turut campur dari kekuasaan ekstra yudisial,termasuk dari pihak lain, bahkan dari pengadilan atau pemimpin yang secara administratif menjadi atasannya.

Ide Negara Hukum tersebut menghilang pada abad pertengahan (600-1400 M) dan muncul kembali pada abad ketujuh belas dan terus berkembang sampai dengan abad kesembilan belas dan awal abad kedua puluh serta awal abad keduapuluh satu sebagai jawaban atas permasalahan perlindungan hak-hak politik manusia dari penyelewengan negara yang dicarinya dari konsep-konsep Yunani-Romawi dengan menyesuaikan pada konteks yang ada pada waktu itu.Tokohnya adalah John Locke kelahiran Wrington Tahun 1632 yang merespon pemerintahan absolut Inggris dibawah Raja Charles II dengan bukunya Two Treatises on Civil Government dan Montesquieu Kelahiran Perancis tahun 1689 yang merespon absloutisme Pemerintahan Perancis dengan Teorinya yang terkenal dengan nama Trias Politica. Segi historis selanjutnya Montesquieu membagi kekuasaan menjadi tiga, yakni:

a. Kekuasaan perundang-undangan, Legislatif;

b. Kekuasaan melaksanakan pemerintahan, Eksekutif;

c. Kekuasaan Kehakiman, Judikatif.
Di Indonesia, negara hukum tercantum pada Undang-Undang Dasar Negara Kesatuan Republik Indonesia Tahun 1945, Pasal 1 ayat 3 Negara Indonesia adalah negara hukum, negara hukum dapat diartikan bahwa suatu negara terdapat suatu peraturan perundang-undangan yang mengatur segala hal. Pada pembagian kekuasaan milik Montesquieu yakni kekuasaan kehakiman, Yudikatif, di Indonesia, kekuasaan kehakiman, sejak awal kemerdekaan juga diniatkan sebagai cabang kekuasaan yang terpisah dari lembaga-lembaga politik seperti MPR/DPR dan Presiden. Namun demikian, sejarah juga mencatat terjadinya penyimpangan dan pasang surut perjalanan kekuasaan kehakiman di Indonesia dari waktu ke waktu, baik yang bersifat administratif maupun bersifat teknis yustisial.

Secara Historis lahirnya kekuasaan kehakiman yang merdeka pernah dikesampingkan dengan lahirnya Undang-Undang Nomor 19 Tahun 1964 tentang pokok-pokok kekuasaan kehakiman, dimana dalam Pasal 19 Undang-Undang tersebut ditentukan demi kepentingan revolusi, kehormatan negara dan bangsa atau kepetingan masyarakat sangat mendesak, Presiden dapat turut campur dalam soal-soal pengadilan. Adanya penyelewengan dan intervensi kekuasaan lain pada institusi kekuasaan kehakiman yang telah terjadi tersebut baik disadari maupun tidak telah mengakibatkan pelumpuhan secara sistemik atas kekuasaan kehakiman di indonesia. Hal ini sangat berpengaruh pada terganggunya sistem peradilan secara keseluruhan dan semuanya itu merupakan penyebab kerusakan terhadap kekuasaan kehakiman yang merdeka dan bertanggung jawab. Pada perkembangan selanjutnya Undang-Undang Nomor 48 Tahun 2009 tentang kekuasaan kehakiman dapat diartikan bahwa kekuasaan kehakiman tersebut diberikan oleh peraturan perundangundangan yang merupakan kekuasaan negara yang merdeka untuk menyelenggarakan peradilan guna menegakkan hukum dan keadilan berdasarkan 
Pancasila dan Undang-Undang Dasar Negara Republik Indonesia Tahun 1945, demi terselenggaranya Negara Hukum Republik Indonesia. Pada suatu kekuasaan yudikatif, peraturan perundangundangan memberikan suatu kewenangan terhadap Pengadilan Militer Utama dalam melakukan pengawasan peradilan militer.

Hukum Administrasi Negara Kewenangan yang biasanya terdiri atas beberapa wewenang adalah kekuasaan terhadap segolongan orang-orang tertentu atau kekuasaan terhadap sesuatu bidang pemerintahan (atau bidang urusan). Bidang Urusan tersebut dapat diartikan bidang urusan kewenangan pengadilan militer utama dalam melakukan pengawasan terhadap pengadilan militer.

Dengan adanya penjelasan diatas,maka dapat dijelaskan lebih luas terhadap suatu rumusan, yakni: Bagaimana Kewenangan Pengadilan Militer Utama Dalam Melakukan Pengawasan Peradilan Militer?, Upaya apa yang dilakukan oleh Pengadilan Militer Utama Dalam Melakukan Pengawasan Peradilan Militer?.

\section{Metode Penelitian}

Penelitian hukum merupakan proses menganalisis suatu aturan dan permasalahan yang ada, serta dalam menganalisis permasalahan yang ada dan menganalisis dari kasus yang dapat diselesaikan dengan peraturan perundang-undangan yang berlaku tersebut dapat menemukan penyelesaian kasus tersebut. Metode Penelitian adalah Empiris Yuridis, yang mana penelitian empiris mengkaji dan menganalisis permasalahan yang ada ke lapangan sehingga menemukan bukti-bukti yang akurat untuk kelancaran penelitian, penelitian yuridis mengkaji dan menganalisis permasalahan yang ada dengan dihubungkan dengan suatu peraturan perundang-undangan yang berlaku. Metode Penelitian ini digunakan untuk menganali- sis Kewenangan Pengadilan Militer Utama Dalam Melakukan Pengawasan Peradilan Militer.

\section{Analisis Dan Pembahasan}

Penelitian Hukum, analisis suatu kasus sangat bermanfaat bagi perkembangan ilmu hukum di masa depan serta dibahas dalam suatu pembahasan yang menjadi satu agar terlihat jelas suatu penelitian dalam bidang ilmu hukum, analisis dan pembahasan yang digunakan,yakni:

\section{Kewenangan Pengadilan Militer Utama dalam Melakukan Pengawasan Peradilan Militer}

Hukum Administrasi Negara, kewenangan yang biasanya terdiri atas beberapa wewenang adalah kekuasaan terhadap segolongan orang-orang tertentu atau kekuasaan terhadap sesuatu bidang pemerintahan (atau bidang urusan) tertentu yang bulat, sedangkan wewenang hanya mengenai sesuatu onderdil tertentu saja. Kewenangan dibidang kehakiman atau kekuasaan mengadili sebaiknya disebut kompetensi atau yurisdiksi. Sebelum masuk dalam kewenangan pengadilan militer utama dalam melakukan pengawasan pengadilan militer dibawahnya,maka terlebih dahulu mengetahui pengertian pengadilan militer serta susunan Pengadilan dalam lingkungan Peradilan Militer yang tercantum pada Undang-Undang Nomor 31 Tahun 1997, Pasal 12 yaitu:

a. Pengadilan Militer;

b. Pengadilan Militer Tinggi;

c. Pengadilan Militer Utama;

d. Pengadilan Militer Pertempuran.

Hal penjelasan untuk Pengadilan Militer, Pengadilan Militer Tinggi, Pengadilan Militer Utama,Pengadilan Militer Pertempuran, dijelaskan dalam pasal-pasal: 
Pasal 8

(1) Pengadilan dalam lingkungan peradilan militer merupakan pelaksana kekuasaan kehakiman dilingkungan Angkatan Bersenjata.

\section{Pasal 9}

Pengadilan dalam lingkungan peradilan militer berwenang:

1. Mengadili tindak pidana yang dilakukan oleh seseorang yang waktu melakukan tindak pidana adalah:

a. Prajurit;

b. Yang berdasarkan undang-undang dipersamakan dengan Prajurit;

c. Anggota suatu golongan atau jawatan atau badan atau yang dipersamakan atau dianggap sebagai prajurit berdasarkan undang-undang;

d. Seseorang yang tidak masuk golongan pada huruf a, huruf b, dan huruf c tetapi atas Keputusan Panglima dengan persetujuan Menteri Kehakiman harus diadili oleh suatu Pengadilan dalam lingkungan peradilan militer.

Pasal 40

Kekuasaan Pengadilan Militer

Pengadilan Militer memeriksa dan memutus pada tingkat pertama perkara pidana yang terdakwanya adalah:

a. Prajurit yang berpangkat Kapten ke bawah;

b. Mereka sebagaiamana dimaksud dalam Pasal 9 angka 1 hurus b dan huruf c yang Terdakwanya termasuk tingkat kepangkatan Kapten kebawah dan;

c. Mereka yang berdasarkan Pasal 9 angka 1 huruf $d$ harus diadili oleh Pengadilan Militer.

Pasal 41

Kekuasaan Pegadilan Militer Tinggi

(1) Pengadilan Militer Tinggi pada tingkat pertama:

a. Memeriksa dan memutus perkara pidana yang Terdakwanya adalah:
1) Prajurit atau salah satu Prajuritnya berpangkat Mayor atas;

2) Mereka sebagaimana dimaksud dalam Pasal 9 angka huruf b dan huruf c yang Terdakwanya atau salah satu terdakwanya termasuk tingkat kepangkatan Mayor atas dan;

3) Mereka yang berdasarkan Pasal 9 angka 1 huruf $d$ haru diadili oleh Pengadilan Militer Tinggi;

b. Memeriksa, memutus, dan menyelesaikan sengketa Tata Usaha Angkatan Bersenjata.

(2). Pengadilan Militer Tinggi memeriksa dan memutus pada tingkat banding perkara pidana yang telah diputus oleh Pengadilan Militer dalam daerah hukumnya yang dimintakan banding;

(3). Pengadilan Militer Tinggi memutus pada tingkat pertama dan terakhir sengketa kewenangan mengadili antara Pengadilan Militer dalam daerah hukumnya.

Pasal 42

Kekuasaan Pengadilan Militer Utama

Pengadilan Militer Utama memeriksa dan memutus pada tingkat banding perkara pidana dan sengketa Tata Usaha Angkatan Bersenjata yang diputus pada tingkat pertama oleh Pengadilan Militer Tinggi yang dimintakan Banding.

Pasal 45

Kekuasaan Pengadilan Militer Pertempuran Pengadilan Militer Pertempuran memeriksa dan memutus pada tingkat pertama dan terakhir perkara pidana yang dilakukan oleh mereka sebagaimana dimaksud dalam pasal 9 angka 1 di daerah pertempuran.

\section{Pasal 46}

Pengadilan Militer Pertempuran bersifat mobile mengikuti gerakan pasukan dan berkedudukan serta berdaerah hukum di daerah pertempuran. 
Sistem Pengawasan yang efektif adalah sarana terbaik untuk membuat segala sesuatunya berjalan dengan baik dalam Administrasi Negara, terutama Pengawasan Preventif. Pengawasan represif hanya berguna bilamana:

(a) Dilakukan secara komprehensif dan cukup intensif;

(b) Bilamana laporannya bersifat cukup obyektif dan analisis dan;

(c) Bilamana laporannya disampaikan cukup cepat.

Pengawasan adalah proses kegiatan-kegiatan yang membandingkan apa yang dijalankan, dilaksanakan, atau diselenggarakan itu dengan apa yang dikehedaki, direncakan atau diperintahkan. Selain itu Pengawasan dapat bersifat:

(1) Politik,bilamana yang menjadi ukuran atau sasaran adalah efektivitas dan atau legitimasi;

(2) Yuridis (hukum) bilamana tujuannya adalah menegakkan yuridikitas dan atau legaalitas;

(3) Ekonomis,bilamana yang menjadi sasaran adalah effisiensi dan teknologi;

(4) Moril dan Susila,bilamana yang menjadi sasaran dan tujuan adalah mengetahui keadaan moralitas $($ Moral $=$ Morals $;$ Moril $=$ Morale $)$.

Agar dapat efektif setiap pengawasan harus memenuhi kriteria tertentu. Kriteria penting bagi pengawasan yang baik, yaitu:

1. Informasi yang akan diukur harus akurat;

2. Pengawasan harus dilakukan tepat waktu disaat penyimpangan diketahui;

3. Sistem Pengawasan yang dipergunakan harus mudah dimengerti oleh orang lain;

4. Pengawasan harus dititikberatkan pada kegiatan-kegiatan strategis;

5. Harus bersifat ekonomis, artinya biaya pengawasan harus lebih kecil dibandingkan dengan hasilnya;

6. Pelaksanaan pengawasan sesuai dengan struktur organisasi.
7. Harus sesuai dengan arus kerja atau sesuai dengan sistem dan prosedur yang dilaksanakan dalam organisasi;

8. Harus luwes dalam menghadapi perubahanperubahan yang ada;

9. Bersifat memerintah dan dapat dikerjakan oleh bawahan;

10. Sistem Pengawasan harus dapat diterima dan dimengerti oleh semua anggota organisasi. (Heidjrachman Ranupandojo, 2000, 14)

Sistem pengawasan yang efektif itu seharusnya mendukung strategis dan memfokuskan diri pada apa yang harus dilakukan,tidak saja pada usaha pengukuran. Pokok perhatian ada pada kegiatan yang penting bagi tercapainya tujuan organisasi. Sistem pengawasan harus mendukung usaha menyelesaikan masalah dengan pengambilan keputusan,tidak hanya menunjukkan penyimpangan-penyimpangan. Sistem tersebut harus dapat menunjukkan mengapa terjadi penyimpangan dan apa yang harusnya dilakukan untuk perbaikkannya.

Sistem pengawasan harus dapat dengan cepat atau dini mendeteksi penyimpangan sehingga tindakan perbaikan dapat pula dilakukan dengan segera agar terhindar dari hal-hal yang tidak diharapkan, bila perlu dengan cara-cara pengecualian. Sistem Pengawasan yang efektif memberikan informasi yang cukup bagi para pengambil keputusan, artinya informasi yang mudah dimengerti dan padat.

Sistem pengawasan harus dapat mengakomodasi situasi yang unik atau yang berubah-ubah. Sistem pengawasan harus pula dapat mengakomodasikan kapasitas seseorang untuk mengawasi dirinya sendiri, yang penting harus ada saling percaya, komunikasi, dan partisipasi pihak-pihak yang berkepentingan. Pengawasan diri tercipta bila rancang bangun kerja itu jelas dan pemilihan orang yang mampu bagi pekerjaannya dilakukan dengan baik. 


\section{Kewenangan Pengadilan Militer Utama dalam Melakukan Pengawasan Peradilan Militer \\ Raditya Feda Rifandhana}

Sistem pengawasan harus menitikberatkan pada pengembangan, perubahan dan perbaikan, jika terdapat atau mendapat sanksi dan peringatan itu harus diminimalisir. Kalau sanksi diperlukan haruslah dilaksanakan dengan hati-hati dan manusiawi. Akhirnya sistem pengawasan harus jujur dan objektif artinya tidak memihak dan satusatunya tujuan adalah peningkatan kerja.

Serta mengenai Kewenangan Pengadilan Militer Utama Dalam Melakukan Pengawasan Peradilan Militer. Maka Kewenangan tersebut bersifat Kewenangan Atribusi adalah pemberian kewenangan kepada badan/atau pejabat pemerintahan oleh Undang-Undang Dasar Negara Kesatuan Republik Indonesia Tahun 1945 atau UndangUndang tertera pada Undang-Undang Nomor 30 Tahun 2014 tentang Administrasi Pemerintahan Pasal 1 angka 22, Undang-Undang yang dimaksudkan diatas adalah Undang-Undang Nomor 31 tahun 1997, mengingat bahwa Pengadilan Militer Utama merupakan induk dari Pengadilan dalam lingkungan peradilan militer di Indonesia, yang diberikan kewenangan oleh Undang-Undang.

Pengawasan adalah didefinisikan istilah pengawasan berasal dari kata "awas" yang artinya memperhatikan baik-baik,dalam arti melihat sesuatu dengan cermat dan seksama. Kewenangan Pengadilan Militer Utama Dalam Melakukan Pengawasan Peradilan Militer, memiliki dasar hukum, yakni:

\section{Pasal 44}

(1) Pengadilan Militer Utama melakukan Pengawasan terhadap:

a. Penyelenggaraan peradilan disemua lingkungan Pengadilan Militer,Pengadilan Milliter Tinggi,dan Pengadilan Militer Pertempuran di daerah hukumnya masingmasing

b. Tingkah laku dan perbuatan para hakim dalam menjalankan tugasnya.
Pengawasan yang dilakukan oleh Pengadilan Militer Utama memiliki tujuan agar sistem peradilan militer dapat berjalan dengan baik dari segi yudisial dan finansial.

Tetapi terdapat tujuan pengawasan,adalah mengusahakan agar pekerjaan-pekerjaan terlaksana sesuai dengan rencana yang ditetapkan dan atau hasil yang dikehendaki (Ranupandojo, et al, 2000, 109). Selain memiliki Tujuan dari Pengawasan, maka terdapat Prinsip Pengawasan adalah:

a. Pengawasan harus berlangsung terus-menerus bersamaan dengan pelaksanaan kegiatan atau pekerjaan;

b. Pengawasan harus menemukan, menilai, dan menganalisis data tentang pelaksanaan pekerjaan secara objektif;

c. Pengawasan bukan semata-mata untuk mencari kesalahan tetapi juga mencari atau menemukan kelemahan dalam pelaksanaan pekerjaan;

d. Pengawasan harus memberi bimbingan dan mengarahkan untuk mempermudah pelaksanaan pekerjaan dalam pencapaian tujuan;

e. Pengawasan tidak menghambat pelaksanaan pekerjaan tetapi harus menciptakan efisiensi (hasil guna);

f. Pengawasan harus berorientasi pada rencana dan tujuan yang telah ditetapkan (Ulbert Silalahi, 2002, 178).

\section{Upaya yang Dilakukan oleh Pengadilan Militer Utama dalam Melakukan Pengawasan Peradilan Militer}

Komitmen pemerintah untuk menegakkan supremasi hukum sebagai bagian dari penuntasan agenda reformasi sampai saat ini masih banyak menghadapi kendala. Harapan para pencari keadilan terhadap lembaga peradilan agar benar- 
benar dapat menempatkan dirinya sebagai benteng keadilan terakhir sepenuhnya belum dapat memuaskan semua pihak. Hal ini terbukti dengan masih banyaknya kritik dan sorotan yang ditujukan terhadap lembaga peradilan. Pengawasan merupakan kegiatan yang mempunyai peranan yang sangat penting bagi lancarnya kegiatan suatu organisasi.

Pengawasan bisa menjadi fungsi pengendali bagi manajemen untuk memastikan bahwa rencana-rencana yang telah ditetapkan dapat berjalan secara mulus dan lancar sehingga organisasi bisa mencapai setiap sasaran yang telah ditetapkan. Upaya adalah usaha, akal, untuk mencapai suatu maksud, memecahkan persoalan, mencari jalan keluar (Fuad Hassan, 1999, 1109). Adapun hal-hal yang menjadi upaya Pengadilan Militer Utama Dalam Melakukan Pengawasan Peradilan Militer, yakni:

A. Pengawasan Langsung,yaitu dengan cara melakukan pemeriksaan kepada objek pengawasan, dalam hal ini objek Pengawasannya:

- Penyelenggaraan peradilan disemua lingkungan Pengadilan Militer, Pengadilan Militer Tinggi dan Pengadilan Militer Pertempuran di daerah hukumnya masingmasing. Penjelasan diatas tersebut bahwa objek pengawasannya ditinjau secara langsung terhadap objek pengawasan,hal ini pengawasan terhadap di daerah hukumnya,tercantum pada Undang-Undang Nomor 31 Tahun 1997.

\section{Pasal 14}

Nama, Tempat Kedudukan, dan Daerah Hukum

(1) Tempat kedudukan Pengadilan Militer Utama berada di Ibukota Negara Republik Indonesia;

(2) Nama, Tempat kedudukan, dan daerah hukum pengadilan lainnya ditetapkan dengan Keputusan Panglima;
(3) Apabila Perlu,Pengadilan Militer dan Pengadilan Militer Tinggi dapat bersidang diluar tempat kedudukannya;

(4) Apabila perlu,Pengadilan Militer dan Pengadilan Militer Tinggi dapat bersidang diluar daerah hukumnya atas izin kepala Pengadilan Militer Utama.

B. Pengawasan Tidak Langsung,yaitu dengan menguji atau meneliti atas laporan atau isi dokumen, dapat diartikan bahwa dokumen beserta isi, meneliti atas laporan merupakan beberapa pendekatan kesisteman yang dilakukan oleh Pengadilan Militer Utama.

C. Pengawasan Terhadap Perbuatan Pejabat Peradilan

Dalam Undang-Undang Nomor 31 Tahun 1997 tentang peradilan militer telah dijelaskan kewenangan pengadilan militer utama dalam melakukan pengawasan peradilan militer, dalam hal ini adalah:

Tingkah laku dan perbuatan para hakim dalam menjalankan tugasnya dapat diartikan bahwa pengawasan terhadap tingkah laku perbuatan hakim/ pejabat peradilan dalam hal ini adalah pengawasan terhadap tingkah laku perbuatan (pekerjaan) pengadilan-pengadilan dan para hakim/panitera, yang mengurangi kewajaran jalannya peradilan. Pelaksanaan pengawasan dibidang perilaku pejabat peradilan (hakim dan pejabat kepaniteraan) dilakukan berdasarkan temuan-temuan, penyimpanganpenyimpangan, yang dilakukan oleh Hakim dan pejabat kepaniteraan baik yang ditemukan atas dasar laporan hasil pengawasan internal maupun atas laporan masyarakat, media massa, dan lain-lain pengawasan eksternal. Dalam hal ini lebih dikhususkan untuk perilaku hakim militer pada pengadilan-pengadilan militer yang dibawah kekuasaan pengadilan militer utama, maka dalam menjalankan tugasnya selaku hakim, setiap kinerjanya harus dinilai 
setiap tahun, atau perilakunya dapat dinilai beserta kinerja hakim tersebut selama menjabat sebagai hakim pada pengadilan dalam lingkungan peradilan militer di Indonesia.

\section{Penutup}

Suatu Kewenangan yang diberikan oleh suatu Peraturan Perundang-Undangan sifatnya adalah sah, dikarenakan undang-undang memberikan amanah terhadap suatu bidang pemerintahan yakni Pengadilan Militer Utama,sebab Pengadilan Militer Utama merupakan induk dari Pengadilan Militer lainnya di Indonesia. Kewenangan Pengadilan Militer Utama Dalam Melakukan Pengawasan Peradilan Militer, dalam hal ini sangat diperlukan, dikarenakan sistem peradilan yang ada indonesia dapat berjalan dengan baik dan terarah, lalu untuk perilaku hakim dapat terkontrol serta jauh dari penyimpangan-penyimpangan oleh Pengadilan Militer Utama selaku induk dari Peradilan Militer lainnya. Selain itu Penyimpangan bila terjadi pada perilaku hakimhakim yang selaku pejabat penegak keadilan, maka sanksi yang diberikan harus sesuai dengan berat penyimpangan yang dilakukan oleh hakim beserta pejabat panitera.

Pada suatu kewenangan yang diberikan oleh peraturan perundang-undangan dalam hal ini sifatnya sah, karena undang-undang memberikan amanah yang sangat jelas manfaatnya, dalam hal ini kewenangan pengadilan militer utama dalam melakukan pengawasan peradilan militer sangat perlu dilakukan, agar terciptanya pengadilan yang profesional serta adil, dikarenakan profesional dan adilnya suatu badan peradilan, maka telah menjalankan amanah dari peraturan perundangundangan di Indonesia.

\section{DAFTAR PUSTAKA}

\section{Buku}

Soehino, 1998, Ilmu Negara, Liberty, Yogyakarta.

Atmosudirdjo, Prajudi., 1981, Hukum Administrasi Negara, Ghalia Indonesia,Jakarta.

Fadlil Sumadi,Ahmad., 2013, Pengawasan dan Pembinaan Pengadilan,Setara Press, Malang.

Mustofa Suyuthi, Wildan., 2013, Kode Etik Hakim, Kencana PrenadaMedia Group,Jakarta.

Suadi, Amran., 2014, Sistem Pengawasan Badan Peradilan Di Indonesia, Raja Grafindo Persada, Depok.

\section{Peraturan Perundang-Undangan}

Undang-Undang Dasar Negara Kesatuan Republik Indonesia Tahun 1945.

Undang-Undang Nomor: 31 Tahun 1997 tentang Peradilan Militer.

Undang-Undang Nomor: 48 Tahun 2009 tentang Kekuasaan Kehakiman.

Undang-Undang Nomor: 30 Tahun 2014 tentang Administrasi Pemerintahan. 